\title{
CAPACIDADE E CONSENTIMENTO NA RELAÇÃO MÉDICO-PACIENTE
}




\title{
CAPACIDADE E CONSENTIMENTO NA RELAÇÃO MÉDICO-PACIENTE
}

\author{
Dissertação apresentada à Faculdade de Direito da \\ Universidade de São Paulo, sob orientação da \\ professora doutora Daisy Gogliano, como \\ requisito parcial para obtenção do título de mestre \\ em Direito Civil.
}

Ivan Lobato Prado Teixeira

Faculdade de Direito da UniVERsidade de SÃo Paulo

SÃo PAULO

2009 
"Se o dom tendes de ler

Nas sementes do tempo e de dizerdes

Qual há de germinar e qual não há de,

Falai-me então a mim, que nem vos rogo

Favores nem me temo do vosso ódio"

(William Shakespeare, Macbeth, tradução de Manuel Bandeira)

"Oh que grandes esperanças me dá esta sementeira! Oh que grande exemplo me dá este semeador! Dá-me grandes esperanças a sementeira porque, ainda que se perderam os primeiros trabalhos, lograr-se-ão os últimos. Dáme grande exemplo o semeador, porque, depois de perder a primeira, a segunda e a terceira parte do trigo, aproveitou a quarta e última, e colheu dela muito fruto"

(Pe. Antônio Vieira, Sermão da Sexagésima) 


\section{AGRADECIMENTOS}

À Professora Doutora Daisy Gogliano, não apenas pela orientação precisa e rigorosa, mas também pela compreensão e apoio constantes. Aos Professores Doutores José Luiz Gavião de Almeida e Roberto Augusto de Carvalho Campos, por suas oportunas correções aos rumos do presente trabalho, na ocasião do exame de qualificação. Aos meus pais, Ivan Prado Teixeira e Marlene Teixeira, por tudo o que fizeram por mim (seria impossível, e até injusto, procurar enumerar as razões do agradecimento). Aos Doutores João Marques da Cunha e Gilberto Bergstein, pela amizade e apoio, sem o que o presente trabalho não chegaria a este ponto. A Flávia Serizawa e Silva, pela disposição em discutir questões relacionadas ao tema, sempre sugerindo pontos de vista enriquecedores. Ao amigo Giacomo Groff, por me acolher em Nova York, durante visita ao Hastings Center, onde pude pesquisar boa parte da doutrina bioética que compõe a bibliografia. A Daniel Callahan e a Karen Shea, respectivamente cofundador e bibliotecária do Hastings Center, pela hospitalidade com que lá me receberam. A todos aqueles que prestigiarem o presente trabalho com sua leitura. 